\title{
Latin Tetrica in etymological perspective
}

\author{
Václav Blažek \\ (Masaryk University, Brno)
}

\begin{abstract}
This article analyzes the oronym Tetrica, located by Roman authors in the country of the Sabines. After the documentation and possible relatives in Latin, five hypothetical Indo-European etymologies are discussed, with a special stress on both word-formation and semantic typology. Taking in account these circumstances, a derivation from the root "ter- "to cut, break" seems to be the most promising solution.
\end{abstract}

\section{Keywords}

Indo-European, Latin, oronym, word-formation, semantic motivation, etymology 


\section{Documentation of the oronym}

The mountain or rock called Tetrica was situated by the Roman authors in the Sabine territory. Let us compare the witnesses of three authors in chronological order:

\subsection{Varro (116-27 BCE), De re rustica 2.1.5.}

tertio denique gradu a vita pastorali ad agri culturam descenderunt, in qua ex duobus gradibus superioribus retinuerunt multa, et quo descenderant, ibi processerunt longe, dum ad nos perveniret. etiam nunc in locis multis genera pecudum ferarum sunt aliquot, ab ovibus, ut in Phrygia, ubi greges videntur complures, in Samothrace caprarum, quas latine rotas appellant. sunt enim in Italia circum Fiscellum et Tetricam montes multae.

(Ed. Goetz 1912)

"Finally, with the third stage, they reached, from the pastoral mode of life, the agricultural, retaining in it much of the two former stages, and went on long in the stage which they had reached before they could attain' our present civilization. Even now in many places there are several kinds of wild animals; there are sheep, for instance, in Phrygia, where many flocks are to be seen, and in Samothrace there are wild she-goats of the kind called in Latin rotae. For many exist in the neighbourhood of Mount Fiscellum and Mount Tetrica."

(Transl. Storr-Best 1912)

1.2. Vergilius (70-19 BCE), Aeneid 7.706-717

${ }^{706}$ Ecce Sabinorum prisco de sanguine magnum

${ }^{707}$ agmen agens Clausus magnique ipse agminis instar,

${ }^{708}$ Claudia nunc a quo diffunditur et tribus et gens

${ }^{709}$ per Latium, postquam in partem data Roma Sabinis.

${ }^{710}$ Una ingens Amiterna cohors priscique Quirites,

${ }^{711}$ Ereti manus omnis oliviferaeque Mutuscae;

${ }^{712}$ qui Nomentum urbem, qui Rosea rura Velini,

${ }^{713}$ qui Tetricae horrentis rupes montemque Severum

${ }^{714}$ Casperiamque colunt Forulosque et flumen Himellae,

${ }^{715}$ qui Tiberim Fabarimque bibunt, quos frigida misit

${ }^{716}$ Nursia, et Hortinae classes populique Latini,

${ }^{717}$ quosque secans infaustum interluit Allia nomen.

„Then, one of far-descended Sabine name,

(Ed. Greenough 1900)

Clausus advanced, the captain of a host,

and in himself an equal host he seemed;

from his proud loins the high-born Claudian stem

through Latium multiplies, since Roman power

with Sabine first was wed. A cohort came

from Amiternum and the olden wall

of Cures, called Quirites even then;

Eretum answered and Mutusca's hill 
with olives clad, Velinus' flowery field, nomentum's fortress, the grim precipice of Tetrica, Severus' upland fair, Casperia, Foruli, Himella's waves, Tiber and Fabaris, and wintry streams of Nursia; to the same proud muster sped Tuscan with Latin tribes, and loyal towns beside whose walls ill-omened Allia flows."

(Transl. Williams 1910)

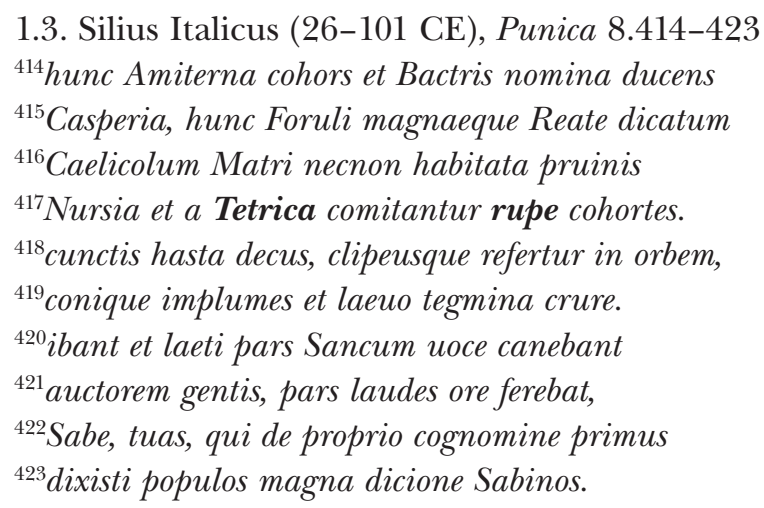

(Ed. Summers \& Postgate 1905)

"With him come the soldiers of Amiterna, and Casperia that takes its name from Bactra (= East), and Foruli, and Reate sacred to the great Mother of the Gods, and Nursia the abode of snow, and warriors from rocky Tetricus. All these carry spears and rounded shields; their helmets have no plume, and they wear greaves on the left leg. As they marched, some of them raised a song in honour of Sancus, the founder of their race, while others praised Sabus, who first gave his name to the wide dominion of the Sabines."

(Transl. Duff 1861)

\section{In Latin there is the closest form the adjective tetricus "forbid- ding, harsh, crabbed, gloomy, sour, stern, severe" = "mürrisch, finster, ernsthaft":}

\subsection{Livius (59 BCE-17 CE), Ab urbe condita 1.18 .4}

suopte igitur ingenio temperatum animum virtutibus fuisse opinor magis instructumque non tam peregrinis artibus quam disciplina tetrica ac tristi veterum Sabinorum, quo genere nullum quondam incorruptius fuit.

"It was his (= Numa's) native disposition, then, as I incline to believe, that tempered his soul with noble qualities, and his training was not in foreign studies, but in the stern and austere discipline of the ancient Sabines, a race incorruptible as any race of the olden time." 


\subsection{Ovidius (43 BCE-17/18 CE)}

\subsubsection{Amores 3.8.61-62}

${ }^{61}$ At nunc, exaequet tetricas licet illa Sabinas,

${ }^{62}$ Imperat ut captae qui dare multa potest

(Ed. Ehwald 1907)

"Now, though she may be as sour as a Sabine, he, who can give much, rules her like a slave."

(Transl. Kline 2001)

\subsubsection{Ars Amatoria 1.721}

${ }^{719} \mathrm{Nec}$ semper veneris spes est profitenda roganti:

${ }^{720}$ Intret amicitiae nomine tectus amor.

${ }^{721}$ Hoc aditu vidi tetricae data verba puellae:

${ }^{722}$ Qui fuerat cultor, factus amator erat.

${ }^{723}$ Candidus in nauta turpis color, aequoris unda

${ }^{724}$ Debet et a radiis sideris esse niger

(Ed. Ehwald 1907)

"The hoped-for love should not always be declared: introduce desire hidden in the name of friendship. I've seen the most severe of women fooled this way: he who once was a worshipper, became a lover.

A pale colour would shame a sailor on the ocean wave, who's blackened by the rays of the sun"

(Transl. Kline 2001)

"Nor must the hope of possession be always proclaimed in your entreaties; let love find entrance veiled in friendship's name.

I have seen an unwilling mistress deluded by this approach;

he who had been an admirer became a lover.

White is a shameful colour in a sailor; swarthy should he be, both from the sea-waves and from heaven's beams."

(Transl. Mozley 1957)

\subsection{Seneca (4 BCE-65 CE), Epistulae 36.3}

Felicem vocabant; quid ergo? Erat? Ne illud quidem curo, quod quibusdam nimis horridi animi videtur et tetrici. Ariston aiebat malle se adulescentem tristem quam hilarem et amabilem turbae. Vinum enim bonum fieri, quod recens durum et asperum visum est; non pati aetatem, quod in dolio placuit. Sine eum tristem appellent et inimicum processibus suis; bene se dabit in vetustate ipsa tristitia, perseveret modo colere virtutem, perbibere liberalia studia, non illa, quibus perfundi satis est, sed haec, quibus tingendus est animus.

"They called him happy: what of it? Was he happy? Even the fact that certain persons he seems a man of a very rough and gloomy cast of mind, does not trouble me. Aristo used to say that he preferred a youth of stern disposition to one who was a jolly fellow and agreeable to the crowd. 'For,' he added, 'wine which, when new, seemed harsh and sour, 
becomes good wine; but that which tasted well at the vintage cannot stand age.' So let them call him stern and a foe to his own advancement. It is just this sternness that will go well when it is aged, provided only that he continues to cherish virtue and to absorb thoroughly the studies which make for culture, - not those with which it is sufficient for a man to sprinkle himself, but those in which the mind should be steeped."

(Ed. \& Transl. Gummere 1917-1925)

2.4. Martialis (40/43-101/102 CE), Epigrammata

(4.73.6) Moverunt tetricas tam pia vota deas.

"such affectionate prayers moved the stern goddesses"

(6.70.8) Et quantum tetricae tulere febres

"and if the amount subtracted from them by cruel fevers"

(7.96.4) Ruperunt tetricae cum male pensa deae.

"when the stern goddesses broke my fatal thread"

(11.2.7) Lectores tetrici salebrosum ediscite Santram

"Fastidious readers may con over the rugged verses of Santra"

(12.70.4) Udorum tetricus censor et asper erat

"he used to be a severe and unsparing censor of drunkards"

(Ed. Heraeus \& Borovskij 1925/1976; Transl. Bohn 1897)

\section{Semantic relation between Tetrica mons or rupes and tetricus}

In Latin there are several adjectives which can be applied to both the mountains or rocks and to negative features of persons or various other phenomena:

\section{1. acūtus}

\subsubsection{Vergilius, Aeneid 8.233}

${ }^{230}$ Ter totum fervidus ira

${ }^{231}$ lustrat Aventini montem, ter saxea temptat

${ }^{232}$ limina nequiquam, ter fessus valle resedit.

${ }^{233}$ Stabat acuta silex, praecisis undique saxis

${ }^{234}$ speluncae dorso insurgens, altissima visu,

${ }^{235}$ dirarum nidis domus opportuna volucrum.

“... and thrice he compass'd round

(Ed. Greenough 1900)

With winged speed the circuit of the ground.

Thrice at the cavern's mouth he pull'd in vain, And, panting, thrice desisted from his pain. 
A pointed flinty rock, all bare and black, Grew gibbous from behind the mountain's back;

Owls, ravens, all ill omens of the night, Here built their nests, and hither wing'd their flight."

"Three times his ire surveyed

(Transl. Dryden 1697)

the slope of Aventine; three times he stormed

the rock-built gate in vain; and thrice withdrew

to rest him in the vale. But high above

a pointed peak arose, sheer face of rock

on every side, which towered into view

from the long ridge above the vaulted cave,

fit haunt for birds of evil-boding wing."

(Transl. Williams 1910)

\subsubsection{Horace, Carmina 4.4.76}

per acuta belli

"of violent, severe misfortunes of the war"

(Ed. Shorey \& Laing 1919)

\section{2. arduus}

3.2.1. Ovid, Metamorphoses 1.316

${ }^{316}$ Mons ibi verticibus petit arduus astra duobus,

${ }^{317}$ nomine Parnasus, superantque cacumina nubes.

(Ed. Magnus 1892)

"where through the clouds Parnassus' summits twain

point upward to the stars, unmeasured height"

(Transl. More 1922)

\subsubsection{Titus Livius, Ab urbe condita 8.16.8}

Corvus, quia id arduum factu erat, labore militum potius quam periculo peragere inceptum voluit.

(Ed. Weissenborn \& Müller 1898)

"Corvus perceived the difficulty of the task and preferred to gain his object by submitting his men to the labours of a regular siege rather than by exposing them to unnecessary risks."

(Transl. Roberts 1912)

\section{3. asper}

\subsubsection{Ennius, Thyestes}

ipse summis saxis fixus asperis, euisceratus

latere pendens, saxa spargens tabo sanie et sanguine atro

(Ed. Jocelyn 1967) 
"He, set disbowelled on sharp steep rugged rocks.

Hanging by his own flank and spattering

The rocks with gore, with mess of black-hued blood"

(Ed. \& Transl. Warmington 1935: pp. 354-355)

3.3.2. Vergilius, Aeneid 7.647

${ }^{647}$ Primus init bellum Tyrrhenis asper ab oris

${ }^{648}$ contemptor divom Mezentius agminaque armat.

"Foremost in fight, from shores Etrurian came

Mezentius, scornful rebel against Heaven"

(Transl. Williams 1910)

3.4. dūrus

3.4.1. Vergilius, Aeneid 6.471

${ }^{469}$ Illa solo fixos oculos aversa tenebat,

${ }^{470}$ nec magis incepto voltum sermone movetur,

${ }^{471}$ quam si dura silex aut stet Marpesia cautes.

${ }^{472}$ tandem corripuit sese, atque inimica refugit

${ }^{473}$ in nemus umbriferum, coniunx ubi pristinus illi

${ }^{474}$ respondet curis aequatque Sychaeus amorem.

"But on the ground she fixed averted eyes.

For all he spoke moved her no more than if her frowning brow

were changeless flint or carved in Parian stone.

Then, after pause, away in wrath she fled,

And refuge took within the cool, dark grove, where her first spouse,

Sichaeus, with her tears mingled his own in mutual love and true."

\subsubsection{Cicero, Pro Archia 8}

Quis nostrum tam animo agresti ac duro fuit ut Rosci morte nuper non commoveretur?

(Ed. Clark 1909)

"Who of us was of so ignorant and brutal a disposition as not lately to be grieved at the death of Roscius?"

(Transl. Yonge 1856)

3.5. It is possible to conclude that the Latin adjective tetricus could originally also had the meaning "sharp" or "steep" or "rough, hard", which was applicable to description of mountains or rocks. 


\section{From the point of view of internal etymology there are two directions of research:}

4.1. If the root was *trei $(\hat{k})$-, primary attested in Latin trīcae "complications, tricks; trifles", intricāre "to entangle, embarrass, perplex" [both from Plautus], the Latin forms Tetrica $\mathcal{E}^{2}$ tetricus should be interpreted as the partial reduplication ${ }^{*}$ tetri $\left(\hat{k}^{\prime}\right.$.

4.1.1. The closest external cognate may be identified in Tocharian AB trik- "to go astray, be confused", B preterit II trāikā-, preterit III treikä $(s \bar{a})$-, preterit participle tetriku A tatriku "false", further B trikșo "error, mistake", traike "confusion, delusion" etc. (Pokorny 1959: p. 1071; Kümmel LIV: p. 648; Malzahn 2010: pp. 668-670; Adams 2013: pp. $334-335,340)$.

4.2. If *-iko- can be identified as a suffix and separated, the base ${ }^{*} t e t r(H)^{\circ}$ remains. The suffix *iko-forms denominative adjectives (not only) in the Italic branch: Latin tenebricus "dark, gloomy" vs. tenebrae "darkness", cìvicus "of a citizen" vs. cìvis "citizen", modicus "having a proper measure" vs. modus "measure” etc.; Oscan túvtíks 'publicus' vs. toutam 'civitatem' etc. (Brugmann 1906: pp. 488-489; Weiss 2009: p. 294).

4.2.1. The base $* \operatorname{tetr}(H)^{\circ}$ can be interpreted in two ways.

4.2.1.1. It may be an $r$-derivative of the root ${ }^{*} t e d$-, since the root of the type *tet- was excluded in the Indo-European protolanguage (e.g. Szemerényi 1996: p. 99) and in Lat-

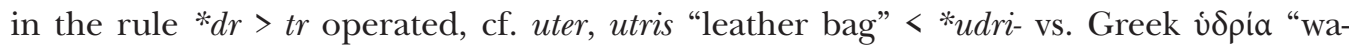
ter-vessel" (de Vaan 2008: pp. 618, 647). But for the hypothetical root *ted- there are no adequate continuants in Latin or Italic, nor Indo-European. A more promising situation is in the case of Latin taeda "resinous fir" or "pine wood, pitch-pine" [Caesar, BG 2.11; 3.101], although the first use of this word in the sense "a pitch pine torch" has been ascribed already to Ennius by Cicero [Academicae Quaestiones 2.28.89]. The tree "fir" as a semantic base to designate a mountain is quite natural, cf. the Austrian Tennengebirge (a part of the Northern Limestone Alps) or Fir Mountain (in New York state, USA). The hypothetical derivative *taidro- would regularly change into *taitro- in Latin. The traces of monophthongisation *ai $>a e>e$ are attested already around 200 BCE, e.g. in Lex Spoletina, where such forms as cedere $\mathcal{E}^{2}$ cedito appear instead of ${ }^{*}$ caed $^{\mathrm{o}}$; cf. also pretod 'praetor' [CIL I ${ }^{2}$ 365: Falerii] ${ }^{1}$ etc. (Leumann 1928: p. 75). The same change is known from the northern neighbors of Latin, namely Faliscan (efiles vs. Latin aedilis) and Umbrian (pre vs. Oscan prai, Latin prae). This solution also allows us to explain the existence of probable derivatives with negative semantics: Latin taedet "it disgusts, offends, wearies", besides taetro "to render foul", taeter "offensive, foul, noisome, shocking, hideous, loathsome". The common semantic denominator may be found in "resin", which has frequently been synonym for "bad luck, misfortune". E.g. German Pech or Czech smůla mean both "pitch, resin" and secondarily "bad luck, misfortune". The weakest side of this 'fir'-solution is the etymology proper of Latin taeda. It seems that there is no better explanation than the adaptation of the accusative $\delta a ̣ \delta \alpha \dot{~ o f ~ A t t i c ~ \delta a ̣ ́ c, ~ g e n . ~} \delta a ̣ \delta$ óc, Homeric

1 EDCS [ID: EDCS-19700173; retrieved 23.9.2021 from http://db.edcs.eu/epigr/epi_einzel.php?s_ sprache=en\&p_belegstelle $=$ CIL $+01,+00365]$. 


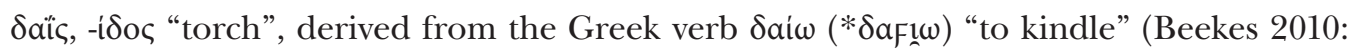
pp. 298-299; Walde \& Hofmann II: p. 642; Ernout \& Meillet 1932: p. 970). The Latin variant with the voiced initial $d$-is known from glosses (CGL II: pp. 265, 58; 496, 53) and there are real Romance continuants: Romanian zadă, Sicilian, Calabrian, Corse deda etc. "torch", besides the voiceless initial in Dalmatian teda "Fichtenharz", Engadine taya "Kienholz", Provençal teza "harziges Fichtenholz, Fackel", Catalonian teya, Portuguese tia "Fackel", Spanish teia "Fackel, Weihrauchkiefer" (Meyer-Lübke 1935: n. 8520).

4.2.1.2. Another possibilty is to assume a partial reduplication *tetr $(H)^{\circ}$. It can be compared with Latin feber "beaver" [Varro, Lingua Latina 5.79], derivable from the $o$-stem ${ }^{*} b^{h} e b^{h} r o$ - in the same way as e.g. sacer "sacred" from *sakro-, really attested in Old Latin SAKROS [Lapis niger; 570-550 BCE] (Weiss 2009: p. 123). The form * $b^{h} e b^{h} r o$ - has usually been explained as the partial reduplication from the anit-root ${ }^{*} b^{h} e r$-, attested e.g. as the vrddhi-formation in Lithuanian béras "(of a horse) bay, chestnut-coloured, light brown", Latvian bẹrs "bay (of a horse)” (Pokorny 1959: pp. 136-137; Smoczyński 2018: pp. 105, 110). The partial reduplication of the set-root can be illustrated by the word ${ }^{*} k^{u} e k^{u} l\left\{H_{1 / 2}\right\}_{0-}$ "wheel": Vedic cakrá-, Young Avestan caxra-; Germanic *hwehla-/*hweula- > Old Norse hjól, Old English hweohhol, hwêol, hweowol, hweogol "wheel" etc., all from the verb $*^{*} e l H_{1 / 2}$ " "to go round" (Weiss 2009: p. 267; Lipp, LIV: pp. 386-388: * $k^{u} e l H_{1}$; Pokorny 1959: pp. 639-640). This means that both variants, the anit-root *ter-and set-root *ter $H_{-}$, are acceptable.

4.2.1.2.1. The corresponding anit-root *ter- may be identified in Hittite tatrant-adj. "sharpedged (stone); agitated, aggressive", tatrahh- "to incite, stirr up" (Kloekhorst 2008: p. 857: IE *der- "to tear"; Neumann apud Tischler 1993: p. 276 already connected Hittite ta-

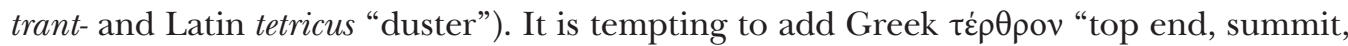
highest point" [h. Merc. 322; Euripides, Fr. 371] and $\tau \dot{\varepsilon} \rho \mu \alpha$ "end, highest point, supreme power" [Il.] \& $\tau \dot{\varepsilon} \rho \mu \omega v$ "end, boundary, edge" [Aeschylus; Euripides] with no traces of any laryngeal after $\rho,{ }^{3}$ which would be expected in the case of derivation from the set-root, in the same way as $\tau \dot{\varepsilon} \rho \varepsilon \tau \rho o v ~ " b o r e r, ~ a u g e r " ~[O d]<.* t e r H_{-}^{-}$"to bore, rub" (Beekes 2010: pp. 1468-1470; see the discussion by Olsen 1988: pp. 9, 34). Its o-grade, probably with the sigmatic extension, may be identified in Brittonic languages: Welsh tor "a breaking, snip, cut, wound; gap, breach, break, interruption, cessation; break (of day); broken", Middle Welsh (1300) torr 'fractio' (GPC), besides Old Welsh torr gl. 'palma' (cf. Matasović 2009: p. 385); Cornish tor "cassure, rupture, fracture"; Breton torr "casse, cassure, rupture; labour" (Deshayes 2003: p. 731); plus the verb: Welsh torri "to break, shatter, smash, fracture, crack, tear, rupture, damage, ruin", Middle Welsh torri / tori "frangere, rumpere" (GPC); Cornish terry, tyrry, torraf "casser; couper"; Middle Breton (1499) terriff, Breton torriñ “(se)casser, (se) rompre; (s’)interrompre; éclore” (Deshayes 2003: p. 731).

2 Fiber, ab extrema ora fluminis dextra et sinistra maxime quod solet videri, et antiqui februm dicebant extremum, ... "The beaver was called fiber because it is usually seen very far off on the bank of the river to right or to left, and the ancients called a thing that was very far off a februm ..." (Transl. Kent 1938). Besides feber was the more frequent form fiber [beginning from Plautus].

3 In agreement with the rule formulated by Byrd (2012: p. 44), in the sequence RHCC, where $R$ is a resonant in the non-first position, continuants of the laryngeal should be preserved. 
A hypothetical continental Celtic counterpart could have been related to (or adopted in) Latin torus "knot, bulge" [Cato, $R R$ 135.4], "fleshy part, muscle" [Cic., Tusc. 2.9.22], "bulge, thickness of trees" [Plin. 17.23.35, 19.8.42], "bolster, cushion" [Verg., A. 5.388], "elevation, bank of earth" [Verg., A. 6.674], "large, round moulding at the base of a column" [Vitr. 3.3.8] (de Vaan 2008: p. 625 thinks about a derivation from the root ${ }^{*} \mathrm{terH}_{2}$ "to cross, go through"), and numerous Romance forms: Italian toro "Säulenwulst", Old Neapolitan torus "Hügel, Abhang", Lombardic tör "Baumstrunk", Monferrinish (Piedmont) tore "die dicksten Äste eines Baumes", Spanish tuero "Scheit Holz", Portuguese toro "Stamm ohne Zweige", besides Old French toron, Provençal torada "Hügel", Alava (North Spain) torillo, toral "runder, glatter Kieselstein", besides Provençal, Portuguese torar "in Blöcke zersägen", South French tura "Säge" etc. (Meyer-Lübke 1935: n. 8811; FEW 13/2: pp. 115-117). Related can be Albanian tarr "to cut (vine)" (Orel 1998: p. 449 connected it with Albanian tjerr "to spin").

4.2.1.2.2. The most promising candidates for the set-root can be identified in $*_{t e r H_{1}}$ " to rub, bore" (Beekes 2010: p. 1468; Kümmel, LIV: p. 632; Pokorny 1959: pp. 1071-1072)

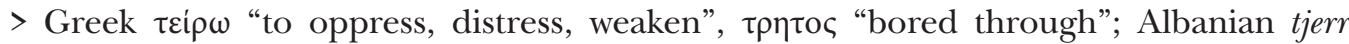
"spinne"; Latin terere "to rub", terebra "drill"; Celtic *taratro- "auger, borer" > Old Irish tarathar m.; Old Welsh tarater, Welsh taradr m., Cornish tardar, Middle Breton tarazr, talazr, Modern Breton tarar m.; (Latinized) Gaulish taratrum, glossed as 'quasi teratrum; scopina dicta, quod haerendo scopim facit' by Isidore, Or. 19.19.15 (Holder 1904: c. 1729; Matasović 2009: p. 370; Delamarre 2018: pp. 290-291); Old Church Slavonic tıre : trěti "to rub" etc., and in *terH 2 $^{-}$"to cross" > Vedic tárati Ẽ tiráti "crosses over, passes through, overcomes, surpasses", tirás "across, over, apart", Young Avestan tar- "to cross over", tarō "über - hin, seitwärts" (Cheung 2007: pp. 380-382); Hittite tarhu $u^{z i}$ "to prevail, be powerful, be able, defeat", Cuneiform Luwian tatarh- "to break", Hieroglyphic Luwian

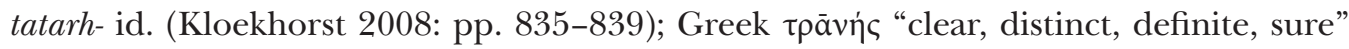
[trag.] < ${ }^{*} \mathrm{tr}_{2} \mathrm{n}_{2}$, cf. English seeing through (Beekes 2010: pp. 1498-1499); Albanian shtir/ shtyr "to cross (a river); push"; Latin trāns "accross, through", Umbrian tra, $\operatorname{trah}^{\circ}<$ *trānts $<* t r H_{2}-n t-s$ (de Vaan 2008: p. 627); similarly Old Welsh tra, Breton treuz "across", besides Old Irish tar E dar "across" < Celtic *taras < *tr $\mathrm{H}_{2} e s$, further Old Irish tre, Old Welsh trui, Middle Welsh trwy, drwy, Cornish dre, Old Breton tre, Middle Breton dre "through", Gaulish [Lezoux; Marcellus of Bordeaux] tri < Celtic *tre < loc. * ${ }^{*}$ treH $_{2}-i$ (Schrijver 1995: pp. 246-247; Matasović 2009: pp. 370, 388; Delamarre 2018: pp. 300-301); Gothic pairh, Old English perh "through", besides Old English purh, Old Saxon thurh, thuru, Old High German duruh id. (see Pokorny 1959: pp. 1074-1075). Schrijver (1995: pp. 144-145) added still the following Brittonic material: Welsh $\operatorname{tardd} \mathrm{m}$. "eruption, issue", tarddu "to sprout, derive from, issue", Middle Cornish tardha "to explode", Breton tarzh m. "explosion, break, eruption", tarzhañ "to explode, break", Old Breton tard < Common Brittonic *tard ${ }^{\circ}<*$ tar-io- n. \& *tar-ie- v. (cf. also Schumacher 2004: p. 620).

4.2.1.3. In the Indo-European languages there are several appellatives and oronyms, which could be derived from one of these roots. Let us analyze them.

4.2.1.3.1. Old French (Roland), French tertre 'monticule, éminence isolée', Old Provençal tertre, Poitevinish terdre, Saintonge tartre, tertre, Morvand of Viteaux tartre, Ardennes 
teltre, Sancey tatre etc., Fribourg tyerdu "Hügel". It has been connected with Latin termen "boundary-stone" 4 Accius], via the derivative *termite attested in Neapolitanish térmete and Friaulish tiármit (Meyer-Lübke 1935: n. 865.3; FEW 13/1: p. 242), but it is rather problematic with regard to the presence of the second $-r$-. More promising seems to be an adaptation of the hypothetical Gaulish form *tertroN or *tertrā, corresponding to Greek $\tau \dot{\varepsilon} \rho \theta \rho o v$ "top end, summit, highest point". The assumed Gaulish form *tertro- or *tertrā can be analyzed as the derivative in *-tro- from the anit-root *ter-, since the setroot ${ }^{*}$ terH $H_{x}$ implies the vocalisation of the laryngeal, which can be illustrated by Celtic *taratro- "auger, borer" (Matasović 2009: p. 370; Delamarre 2018: pp. 290-291; see $\$ 4.2 .1 .2 .2$.). The laryngeal vocalized as $-a$ - is even preserved in the Gaulish borrowings in the Romance languages: Obwaldish tarader, Old French tarere, Provençal taraire, Lyonese taroro, Spanish taladro (> Catalonian taladre), Portuguese trado "borer" (Meyer-Lübke 1935: n. 8570; FEW 13/1: pp. 112-114). The Celtic origin is also probable for Basque tarateilu, var. taratellu, taratuli "grosser Stangebohrer" (Löpelmann 1968: p. 1251). Common Celtic *taratro- has usually been explained via Lex Joseph from *teratro-, which

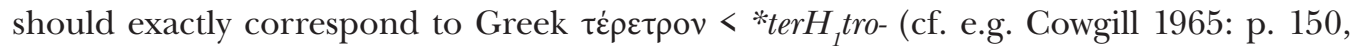
fn. 14; LEIA T-30; Schrijver 1995: pp. 73, 87, 142; Zimmer 2000: p. 442; Zair 2012: p. 167; Byrd 2012: p. 44), ${ }^{5}$ all from *terH ${ }_{1^{-}}$"to rub, bore" (see $\left.\$ 4.2 .1 .2 .2.\right)$. But already Kuryłowicz (1956: pp. 199-201), followed by Zimmer (p.c., June 30, 2021), speculated about the zero-grade ${ }^{*}$ tr $_{1}$ tro- and Hamp (1983: p. 91) even ${ }^{*} t_{\circ} H_{1}$ etro-; see the detailed discussion by de Bernardo Stempel (1987: pp. 44-45, 144) and Schrijver (1995: p. 87).

4.2.1.3.1.1. Let us mention that Muller (1926: pp. 482-483) derived both the Latin adj. tetricus and the oronym Tetrica mons from *tetro- + suffix *-ico-, further via dissimilation from *tertro-, and finally from the root now reconstructed as *terH $H_{1^{-}}$"to rub, bore", with the laconic notice to semantics: "durchdringen" "spitz, scharf" (cf. also Walde \& Hofmann II: p. 678, although they expressed doubts concerning *tertro-). But in this case one would expect the development ${ }^{*}$ terH $H_{1}$ tro- $>$ Common Celtic *taratro- discussed in $\$ 4.2 .1 .3 .1$.

4.2.1.3.2. Middle Irish tethra, gen. tethrach is known from O'Davoren's Glossary, n. 1562: tethrach .i. traigh, i.e. "strand" (Stokes 1904: p. 476; DIL T-162). It is derivable from Proto-Celtic *tetrā $k^{\circ}$, perhaps in the same way as Old Irish cauru, levelled caíra f., gen. cáerach

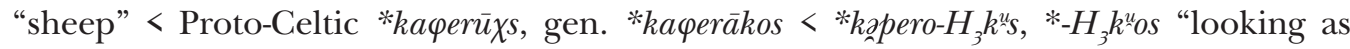
a goat" (Stifter 2020: pp. 32-34; cf. further Thurneysen 1946: p. 203; LEIA T-56; Delamarre 2018: p. 97; Brugmann 1906: p. 500). If it is the case, Proto-Celtic *tetrā $k^{\circ}$ would mean * "having a shape of *tetr". Let us mention that a homonym was recorded, glossed as muir, i.e. "sea", and $b a d b$, i.e. "scaldcrow". It was also used in an adjectival use in the

4 Perhaps only Old Walloon ter $\mathrm{m}$. 'montagne, colline' (end of the $12^{\text {th }}$ cent.), Wallon tiêr id. (FEW 13/1: p. 242) can represent the continuants of Latin termen with respect to the semantics of Dordogne terme "Hochebene" or Romanian tărm "shore" (Meyer-Lübke 1935: n. 8665).

5 Byrd (2012: p. 44) explains, why the rule ${ }^{*} C H C C>{ }^{*} C C C$ formulated by Hackstein (2002) is valid only for the sequence $* T H C C$, where $T=$ obstruent, while in the sequence $* R H C C$, where $R=$ resonant in the

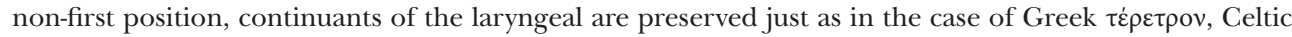
*taratro-, Latin terebra $<{ }^{*} t e r H_{1} d^{h} r \bar{a}$. 
sense "deadly": cia teidm tethra dothait forsna sluagu "what deadly plague has fallen on the hosts" (Weiss, p.c.; Stokes 1893: pp. 418-419). The same name Tethra was borne by one of the Fomorian kings, ruling over the sea, whose wife was Badb (LEIA T-56; DIL T-16162; Stokes 1891: p. 130). If the word tethra "strand" is not only an artificial construction, it can be related to Latin tetricus, but it is impossible to differentiate between its source in the root ${ }^{*}$ ter- or ${ }^{*}$ terH $H_{2}$.

4.2.1.3.3. Iranian *tära-/*tara- > Khotanese ttāra- 'forehead, top of head' (Bailey 1979: pp. 125-126); Sogdian Buddhist t'r 'summit, forehead' / tār/ (Gharib 1995: n. 9487), Yaghnobi $t \bar{o} r$ 'top, summit', tōrk 'top of the mountain' (Novák 2010: p. 173); Šughni tīr, Khufi tor, Bartangi tör, Rošani, Orošori tü̈r, Sarikoli ter 'top', postp. 'up, above, on the top of', Yazghulami tưr 'above' < *tara-, while Šughni tōr 'top, summit' < Persian tār 'top, summit' (Morgenstierne 1974: p. 81); Ormuri tâlâk 'crown of the head' (Morgenstierne 1929: p. 410); Ossetic Iron tar, Digor itare 'breast' < *(ui-)tāra- (Abaev III: p. 231), Ossetic Digor ter-nix, Iron ter-nyx 'forehead' (Abaev III: pp. 270-271) < *tara- Eं *anīka- (cf. Abaev II: pp. 218-219); New Persian tār 'top, summit, vertex, pinnacle, head or higher part of anything', târak 'the top, the crown of the head; a helmet; the head of a lance or spear; a little hill, a heap; giddiness' (Steingass 1892: p. 274).

The Iranian form *tara- can reflect IE *tero-, *terHo- and *torHo-, but not *toro-, which should lead to the lengthening of the root vowel in the Indo-Iranian level with respect to the Lex Brugmann, i.e. *tāra-. So, Iranian *tara- is explainable from both the roots *ter- $\mathcal{E}^{*}{ }^{*}$ terH $\mathrm{H}_{2}$.

The Iranian form *tära- can reflect the protoform *toro- lengthened thanks to the Lex Brugmann or some vrddhi-formation of the root $* t_{0} H_{2}$ (cf. Avestan hama-/hāma- discussed by Darms 1978: p. 172).

4.2.1.3.4. The High Tatra mountains on the border between Slovakia and Poland with its Gerlachovský štít (2655 m) represent the highest part of the Carpathian mountain range. The oronym was firstly recorded by Cosmas of Prague in his Chronica Boemorum, finished to AD 1125 (Bretholz 1923: pp. 60, 138):

(1.33) to AD 999: usque ad montes, qui sunt ultra Krakov nomine Tritri (var. Trytri, Triti, Tryti)

(2.37) to AD 1086: inde Ungarorum limitibus additis quibus nomen Tritri (var. Tirtri, Triti, Tatri).

In Hungarian chronicles from the $12^{\text {th }}-14^{\text {th }}$ cent. the mountains were called Turtur, ${ }^{6}$ Turtul, Tortol. Two liquids are still preserved in the Ukrainian oronym Tóltry (Ẽ Tóvtry), alternatively Medubory, designating the low mountain ridge parallel with the Carpathians, situated in Podolye (West Ukraine) and North Moldova. Remarkable is the existence of the mountain called Trtra or Trtla (Planina) in Herzegovina (height $681 \mathrm{~m}$; situated in west from Mostar), i.e. in the West-Central Balkan, outside the Carpathian range (Asbóth 1912: pp. 203-204). In the North Carpathian area the oronym has also been used in the appellative function: Slovak dial. (Spiš) pl. tatry "mountain peaks", Ukrainian dial. (Boikos) tatra "rock on the highest mountains, where only modest plants grow", besides

6 Anonymus, $\$ 18$ (to AD 1150): usque ad montem Turtur, per montes Turtur, ibid. § 57: ad montem Turtur (cf. Melich 1913: p. 172), later (AD 1273) Turtul (cf. Pražák 1988: p. 241). 
Ukrainian tóvtry “(Felsen) Steine am Boden eines Flusses” (Żelechowski \& Niedzielski 1886: p. 971), toltry "rocky hill" (Rozwadowski 1914: p. 13). These appellative forms are apparently transferred from propria and not vice versa (Melich 1913: p. 174). As a textbook example can serve the same functional shift from a hydronym to an appellative in Slavic, namely Old Church Slavonic Dunavz, Bulgarian Dúnav, Serbo-Croatian Dünâj E Dünav, Czech, Slovak, Polish Dunaj, Old Russian Dunai "Danube" vs. Polish dunaj "remote, unknown river; sea”, Ukrainian dunáj "flood”, Russian dial. dunáj "rivulet flowing under the earth" (ESSJ 5: p. 156). That is why the oronym Tatra with its older forms has been taken as an adaptation of some substrate mountain-name. The old records imply two earliest forms, which may be projected into Proto-Slavic, namely *Trrtry (Asbóth 1912: p. 204; Melich 1913: p. 174; Vasmer 4: pp. 27-28) on the basis of the Hungarian chronicles, Polish Tatry ${ }^{7}{ }^{*}$ Tartry and perhaps Ukrainian Tóltry Ẽ Tóvtry, and the parallel variant *Tortry or *Trstry, with regard to Cosmas' variants Tritri E Tirtri. Serbo-Croatian Trtra or Trtla can reflex both *Tzrtra or *Tortra. Melich (1913: p. 174) and Rozwadowski (1914: p. 12) projected *Trrtra in the more archaic starting-point ${ }^{*} t r t r^{\circ}$, but it is applicable to ${ }^{*}$ Tortry too. Rozwadowski (1914: p. 14) offered various external com-

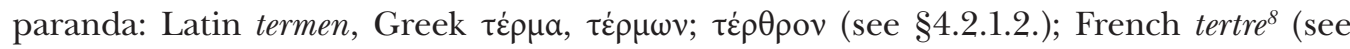

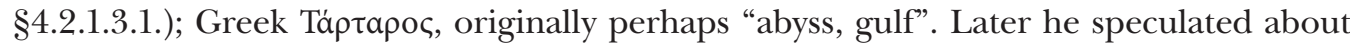
its 'Pannonian-Illyrian' origin (Rozwadowski 1916: p. 18), but without any material support from Palaeo-Balkanian languages. If Albanian is the only living descendant of some Palaeo-Balkanian language (Illyrian?, Dacian?), there is probably at our disposal only one doubtful Albanian comparandum from the same semantic field, namely toritsë "Klippe" (Meyer 1891: p. 433). But it stands too far from the oronym *Tortry or *Tzrtry. More promising seems to be the projection of Melich's \& Rozwadowski's protoform *trtr ${ }^{\circ}$ into Common Celtic and Common Germanic, namely *tritr ${ }^{\circ}$ and ${ }^{*} t u r t r^{\circ}$ respectively. The Slavic projections *Tortry/*Trstry and *Trrtry look like their adaptations. To judge these attractive speculations, we have at our disposal the historical description of the ethnological situation in the territory of present-day Slovakia according to Tacitus ${ }^{9}$ (Germania 43)

7 First by Długosz (1415-1480), I.12: in Alpibus altissimis Hungariae, quorum nivalis sem per verte, qui Thatri a vulgo appellantur ... Item Poprod cuius fons ex monte Pannonico Thatri ...; II.438: tanto nivium congeries descendit, Alpibus Sarmaticis, qui Poloniam et Hungariam dividunt, et aliis, quos Thatri appellamus, ad Keszmark sitis (see Melich 1913: pp. 173-174). The Slovak form Tatry (first 1783) was adopted from Polish (Melich 1913: p. 174). The enigmatic form Tartri appearing in the ms. Beschreibung des wundervollen Karpathischen Schneegebirges by Jakob Buchholz (1752) was probably created artificially according to the form Tartarey used in the same sentence: 'Diese Karpatischen Schneegebirge nehmen ihren Anfang aus der Tartarey (i.e. Moldova); daher in der slowakischen oder wendischen Sprache Tartri genennet werden ...' (Melich 1913: pp. 174-175).

8 Rozwadowski consulted about the origin of French tertre with Wilhelm Meyer-Lübke, the leading Romanist of his time, who had admitted its adaptation of the hypothetical Gaulish source reconstructible as *tertaro- or *tertero-.

9 Retro Marsigni, Cotini, Osi, Buri terga Marcomanorum Quadorumque claudunt. e quibus Marsigni et Buri sermone cultuque Suebos referunt: Cotinos Gallica, Osos Pannonica lingua coarguit non esse Germanos, et quod tributa patiuntur. partem tributorum Sarmatae, partem Quadi ut alienigenis imponunt: Cotini, quo magis pudeat, et ferrum effodiunt. omnesque hi populi pauca campestrium, ceterum saltus et vertices montium insederunt. dirimit enim scinditque Suebiam continuum montium iugum, ultra quod plurimae gentes agunt, ex quibus latissime patet Lugiorum nomen in plures civitates diffusum. (Ed. Furneaux 1900). 
from the end of the 1st cent. AD. From this witness it is possible to conclude that Tacitus ascribed the Celtic origin to Cotini and Pannonian origin to Osi. Both tribes were subjugated by the Germanic tribe Quadi. This means that the Cotini $\mathcal{E}$ Osi probably preceded the Quadi as inhabitants of contemporary Slovakia. The last mention of Cotini ${ }^{10}$ appears in "Roman History" by Dio Cassius (c. 155-c. 235 AD) in his description of "Marcomannic wars' (166-180 AD), led by Marcus Aurelius (121-180 AD). In any case, it is probable that Continuum montium iugum "continuous mountain-range", separating these tribes from the Lugii in contemporary South Poland, represented the \{High\} Tatra mountains. And it is legitimate to expect that at least the highest part of this mountain-range had both Celtic and Germanic names, used in parallel fashion in the first half of the 1st mill. AD. If the first Slavs settled Slovakia during the 6th cent. AD and adopted the rich net of pre-Slavic hydronyms, it is probable that they also borrowed the names of the highest or most striking mountains, serving for orientation. The reconstruction *trtro-, pl./coll. *trtrā-, proposed more or less already by Rozwadowski (1914: p. 12), can be interpreted as a tool-name in *-tro- $/{ }^{*}$-tra - from the anit-root *ter- "to cut, break", similarly as Celtic *taratro- $<*$ terH $H_{1}$-tro- or *trH $H_{1}$-tro- from the set-root *terH $H_{1}^{-}$"to rub, bore" (see above). Toolnames may have really been used for semantic motivation of orographic terms through

"Behind them the Marsigni, Cotini, Osi, and Buri, close in the rear of the Marcomanni and Quadi. Of these, the Marsigni and Buri, in their language and manner of life, resemble the Suevi. The Cotini and Osi are proved by their respective Gallic and Pannonian tongues, as well as by the fact of their enduring tribute, not to be Germans. Tribute is imposed on them as aliens, partly by the Sarmatæ, partly by the Quadi. The Cotini, to complete their degradation, actually work iron mines. All these nations occupy but little of the plain country, dwelling in forests and on mountain-tops. For Suevia is divided and cut in half by a continuous mountain-range, beyond which live a multitude of tribes. The name of Lugii, spread as it is among many states, is the most widely extended." (Transl. Church \& Brodribb 1942).

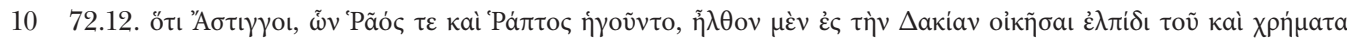

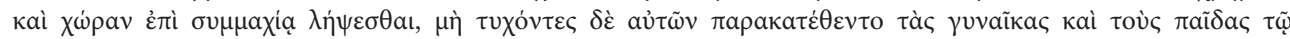

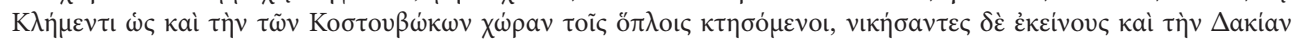

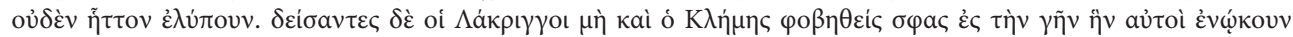

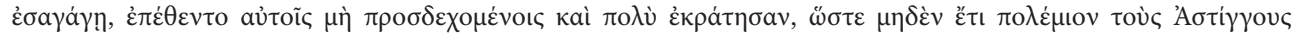

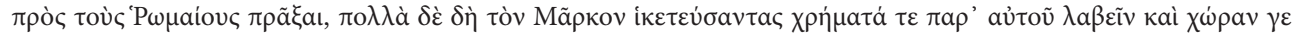

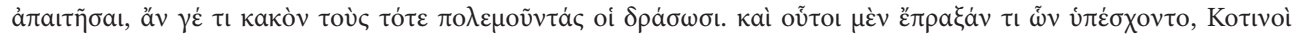

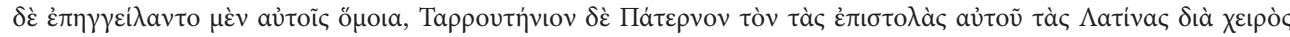

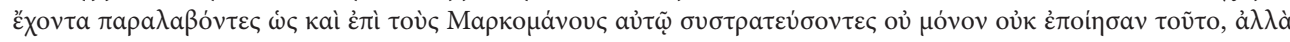

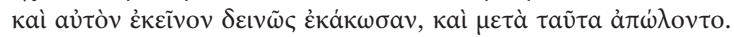

72.12. "The Astingi, led by their chieftains Raüs and Raptus, came into Dacia with their entire households, hoping to secure both money and land in return for their alliance. But failing of their purpose, they left their wives and children under the protection of Clemens, until they should acquire the land of the Costoboci by their arms; but upon conquering that people, they proceeded to injure Dacia no less than before. The Lacringi, fearing that Clemens in his dread of them might lead these newcomers into the land which they themselves were inhabiting, attacked them while off their guard and won a decisive victory. As a result, the Astingi committed no further acts of hostility against the Romans, but in response to urgent supplications addressed to Marcus they received from him both money and the privilege of asking for land in case they should inflict some injury upon those who were then fighting against him. Now this tribe really did fulfill some of its promises; whereas the Cotini, though they made similar offers, nevertheless, upon receiving Tarrutenius Paternus, the secretary in charge of the emperor's Latin correspondence, on the pretext that they wished to make a campaign with him against the Marcomani, not only failed to do so, but even treated Paternus himself shamefully, thereby bringing about their own destruction later." (Ed. \& Transl. Cary \& Foster 1914-1927). 
their visual or functional analogy, e.g. Slavic *burdo "weaving comb" and hence "hill" or "mountain ridge consisting of low hills", or Slavic *xribs "hill", Moravian Chriby mountains, explainable as adaptation of West Germanic *xrībōn "rake" (see Blažek 2020), or Old Italian, Provençal, Portuguese serra, Spanish sierra "mountain ridge", besides original "saw" < Latin serra "saw" (Meyer-Lübke 1935: n. 7861). The hypothetical tool, which had to serve as a motivation for the naming the High Tatra mountains, besides the lower Tóltry / Tóvtry in Podolye and Trtra / Trtla (Planina) in Herzegovina, could be something like "pickaxe" or "saw". Although continuants of *trtro-, pl./coll. *trtrāa-, are not directly attested, this formation is a regular derivative of the root *ter- (see \$4.2.1.2.1.).

\section{Conclusion}

The preceding arguments allow us to formulate the following conclusions:

5.1. The Latin oronym Tetrica is compatible with the adj. tetricus "forbidding, harsh, crabbed, gloomy, sour, stern, severe", if the primary meaning of the oronym was "sharp, steep, rough, hard" vel sim. (see §3).

5.2. In the etymological perspective there are several candidates:

5.2.1. *trei $i \hat{k}$ - “to complicate” (\$4.1.1.).

5.2.2. The $r$-derivative of Latin taeda "a pitch pine torch; resinous fir, pine wood, pitchpine" < Greek (\$4.1.2.1.).

5.2.3. *ter- "to cut, break" (cf. $\$ \$ 4.2 .1 .2 .1 . ; 4.2 .1 .3 .1 . ; 4.2 .1 .3 .3 . ; 4.2 .1 .3 .4$.$) .$

5.2.4. *terH $H_{1}^{-}$"to bore, rub” (cf. $\left.\$ \$ 4.2 .1 .2 .2 . ; 4.2 .1 .3 .1 .1.\right)$.

5.2.5. *terH $\mathrm{H}^{-}$"to cross" (cf. $\$ 4$-2.1.2.2.).

5.3. From these five possibilities the most promising one seems to be the derivation of the oronyms Tetrica and Pre-Slavic *Trtrā (perhaps of Celtic origin), and appellatives represented by Greek $\tau \dot{\varepsilon} \rho \theta \rho o v$ "top end, summit, highest point”, Gaulish > French tertre "hill" etc., from the root *ter- "to cut, break" (\$5.2.3.) for both the phonological reasons (anit-root) and semantic typology - cf. e.g. Latin rüpes "cliff, crag" from rumpere, perf. rūpi "to break open", or saxum "rock, boulder" from secāre "to cut" (cf. Schrijver 1991: p. 422 about the ablaut $T e T: T T>T e T: T a T)$. The same semantic pattern can be applied to Middle Irish tethra, gen. tethrach "strand" (\$4.2.1.3.2.); cf. English shore vs. to shear, Old English sceran "to cut, shear", or Latin ripa "riverbank" vs. Old Norse rifa "to tear to pieces", or Old Norse bakki "riverbank" vs. Sanskrit bañj- "to break" etc. (Buck 1949: $\S \S 1.27 ; 1.44)$.

5.4. The roots *ter- "to cut, break" and *terH $H_{1^{-}}$"to bore, rub" can be related - the latter may represent a laryngeal extension of the former one, naturally with a slight semantic shift. 


\section{Bibliography}

Abaev, V. I. (1958, 1973, 1978, 1989, 1995). Istoriko-ètimologičeskij slovaŕ osetinskogo jazyka. Vol. I. Moskva - Leningrad: Izdatel'stvo Akademii nauk; Vols. II, III, IV. Leningrad: Nauka; Vol. V. Moskva: Institut jazykoznanija RAN.

Adams, D. Q. (2013). A Dictionary of Tocharian B (Vols. 1-2). Amsterdam - New York: Rodopi.

Asbóth, O. (1912). Tátra. Nyelvtudomány, 4, 198-206.

Bailey, H. W. (1979). Dictionary of Khotan Saka. Cambridge: Cambridge University Press.

Beekes, R. (2010). Etymological Dictionary of Greek (with assistance of Lucien van Beek; Vol. I-II). Leiden - Boston: Brill.

de Bernardo Stempel, P. (1987). Die Vertretung der indogermanischen liquiden und nasalen Sonanten im Keltischen (Innsbrucker Beiträge zur Sprachwissenschaft, 54). Innsbruck: Institut für Sprachwissenschaft der Universität Innsbruck.

Blažek, V. (2020). Chřiby a Brdo - toponymická bilingva? Acta onomastica, 61(1), 20-28.

Bohn, H. G. (Transl.). (1897). Martial: The Epigrams. London: Bell \& Sons [retrieved 23. 9. 2021 from http://www.tertullian.org/fathers/martial_epigrams_00eintro.htm].

Bretholz, B. (Ed.). (1923). Die Chronik der Böhmen des Cosmas von Prag (unter Mitarbeit von W. Weinberger; Monumenta Germaniae Historica, Scriptores Rerum Germanicarum, Nova series, II). Berlin: Weidmann.

Brugmann, K. (1906). Grundriss der vergleichenden Grammatik der indogermanischen Sprachen (Vol. 2.1). Strassburg: Trübner.

Buck, C. D. (1949). A Dictionary of Selected Synonyms in the Principal Indo-European Languages. Chicago - London: University of Chicago Press.

Byrd, A. M. (2012). Predicting Indo-European syllabification through phonotactic analysis. In B. N. Whitehead et al. (Eds.), The Sound of Indo-European. Phonetics, Phonemics, and Morphophonemics (pp. 33-52). Copenhagen: Museum Tusculanum Press.

Cary, E., \& Foster, H. B. (Eds. \& Transl.). (1914-1927). Cassius Dio Cocceianus: Roman History. London: Heinemann [retrieved 24.9.2021 from http://data.perseus.org/citations/urn:cts:greekLit:tlg0385.tlg001.perseus-grc1:72; https:/ / penelope.uchicago.edu/Thayer/E/Roman/Texts/ Cassius_Dio/ $72 *$.html].

CGL = Corpus Glossarium Latinorum. (1888-1901). Ed. G. Götz (Vols. II-VII). Leipzig: Teubner.

Cheung, J. (2007). Etymological Dictionary of the Iranian Verb. Leiden - Boston: Brill.

Church, J., \& Brodribb, W. J. (Transl.). (1942). Cornelius Tacitus: Germania and its tribes. In Iidem (Transl.), Complete Works of Tacitus. New York: Random House.

Clark, A. (Ed.). (1909). M. Tullius Cicero: Pro Archia poeta oratio. In Idem (Ed.), Orationes. Oxford: Clarendon Press.

Cowgill, W. (1965). Evidence in Greek. In W. Winter (Ed.), Evidence for Laryngeals (pp. 142-180). London - The Hague - Paris: Mouton \& Co.

Darms, G. (1978). Schwäher und Schwager, Hahn und Huhn. Die Vrddhi-Ableitung im Germanischen (Münchener Studien für Sprachwissenschaft, Neue Folge, Beiheft 9). München: Kitzinger.

Delamarre, X. (2018). Dictionnaire de la langue gauloise. Une approche linguistique du vieux celtique continental (3. ed.). Paris: Errance.

Deshayes, A. (2003). Dictionnaire étymologique du breton. Abri du Marin: Le Chasse-Marée. 
DIL = Dictionary of the Irish Language. (1998). Dublin: Royal Irish Academy (Compact Edition).

Dryden, J. (Transl.). (1697). Vergil: Aeneid. In Idem et al. (Transl.), The Works of Virgil: containing his Pastorals, Georgics, and Aneis. London: Tonson.

Duff, J. D. (Transl.). (1861). Silius Italicus: Punica. London - Cambridge (Mass.): Heinemann; Harvard University Press.

EDCS = Epigraphik-Datenbank Clauss / Slaby [online; www.db.edcs.eu; accessed 23.09.2021].

Ehwald, R. (Ed.). (1907). P. Ovidius Naso: Amores, Epistulae, Medicamina faciei femineae, Ars amatoria, Remedia amoris. Leipzig: Teubner.

Ernout, A., \& Meillet, A. (1932). Dictionnaire étymologique de la langue latine. Histoire des mots. Paris: Klincksieck.

ESSJ = Étimologičeskij slovaŕ slavjanskix jazykov. (1978). Ed. O. N. Trubačev (Vol. 5). Moskva: Nauka. FEW = Französisches etymologisches Wörterbuch - eine Darstellung des galloromanischen Sprachschatzes . (1928-2003). Ed. W. von Wartburg et al. Basel: Helbing \& Lichtenhahn; Zbinden - Paris: Champion; Genève: Slatkine [retrieved 24.9.2021 from https://apps.atilf.fr/lecteurFEW/index.php/ page/view].

Foster, B. O. (Transl.). (1919). Livy: The History of Rome. Book 1 EV 2. Cambridge (Mass.) - London: Harvard University Press; Heinemann.

Furneaux, H. (Ed.). (1900). Cornelius Tacitus: De Origine et Situ Germanorum Liber. In Idem (Ed.), Opera Minora - Cornelius Tacitus. Oxford: Clarendon Press.

Gharib, B. (1995). Sogdian dictionary: Sogdian - Persian - English. Tehran: Farhangan Publications.

Goetz, G. (Ed.). (1912). M. Terenti Varronis Rerum rusticarum libri tres. Lipsiae: Teubner [retrieved 24.09.2021 from https://archive.org/details/rerumrusticaruml00varruoft].

$G P C=$ Geiriadur Prifysgol Cymru - A Dictionary of the Welsh Language. (1967-2002). Aberystwyth: Canolfan Astudiaethau Addysg [online; https://welsh-dictionary.ac.uk/gpc/gpc.html; accessed 24. 9. 2021].

Greenough, J. B. (Ed.). (1900). Vergil: Bucolics, Aeneid, and Georgics. Boston: Ginn \& Co.

Gummere, R. M. (Ed. \& Transl.). (1917-1925). Seneca: Ad Lucilium Epistulae Morales. Cambridge (Mass.) - London: Harvard University Press; Heinemann.

Hackstein, O. (2002). Uridg. *CH.CC > *C.CC. Historische Sprachforschung, 115, 1-22.

Hamp, E. P. (1983). Varia XII. OIr. TALAM, TARATHAR. XIII. Welsh HYDREF, Breton HERE. Études celtiques, 20(1), 91-92.

Heraeus, W., \& Borovskij, J. (Eds.). (1925/1976). M. Valerii Martialis Epigrammaton libri. Leipzig: Teubner.

Holder, A. (1904). Alt-celtischer Sprachschatz (Vol. II). Leipzig: Teubner.

Jakubovich, Ae., \& Pais, D. (Eds.). (1937). P. magistri qui Anonymus dicitur Gesta Hungarorum.

In I. Szentpétery (Ed.), Scriptores rerum Hungaricarum tempore ducum regumque stirpis Arpadianae gestarum (Vol. 1; pp. 33-117). Budapest: Academia Litter. Hungarica et al.

Jocelyn, H. D. (Ed.). (1967). The Tragedies of Ennius. Cambridge: Cambridge University Press [retrieved 22.09.2021 from https://latin.packhum.org/loc/43/5/0\#0].

Kent, R. G. (Transl.). (1938). Varro: On the Latin language. London - Cambridge (Mass.): Heinemann; Harvard University Press.

Kline, A. S. (Transl.). (2001). Ovid: The Amores [retrieved 21.9.2021 from https://www.poetryintranslation.com/PITBR/Latin/AmoresBkIII.php\#anchor_Toc520536664]. 
Kline, A. S. (Transl.). (2001). Ovid: The Art of Love [retrieved 21.9.2021 from https://www.poetryintranslation.com/PITBR/Latin/ArtofLoveBkI.php].

Kloekhorst, A. (2008). Etymological Dictionary of the Hittite Inherited Lexicon. Leiden - Boston: Brill. Kuryłowicz, J. (1956). Lapophonie en indo-européen. Wrocław: Zakład imienia Ossolińskich.

LEIA = Vendryes, J. (1978). Lexique étymologique de l'irlandais ancien (T-U) (ed. E. Bachellery, \& P.-Y. Lambert). Dublin: Institute for Advanced Studies - Paris: CNRS Éditions.

Leumann, M. (1928). Lateinische Grammatik. Laut- und Formenlehre. Syntax und Stylistik. München: Beck.

Lewis, Ch. T., \& Short, Ch. (1894). Latin Dictionary. Oxford: Clarendon Press.

LIV = Kümmel, M., Zehnder, Th., Lipp, R., \& Schirmer, B. (2001). Lexikon der indogermanischen Verben (ed. H. Rix; $2^{\text {nd }}$ ed.). Wiesbaden: Reichert.

Löpelmann, M. (1968). Etymologisches Wörterbuch der baskischen Sprache. Dialekte von Labourd, Nieder-Navarra und La Soule. Berlin: Walter de Gruyter \& Co.

Machek, V. (1931). Tatry. Naše řě́, 15(5), 119-120.

Magnus, H. (Ed.). (1892). Ovidius: Metamorphoses. Gotha: Perthes.

Malec, M. (2003). Stownik etymologiczny nazw geograficznych Polski. Warszawa: Wydawnictwo Naukowe PWN.

Malzahn, M. (2010). The Tocharian Verbal System. Leiden: Brill.

Matasović, R. (2009). Etymological Dictionary of Proto-Celtic. Leiden - Boston: Brill.

Melich, J. (1913). Über die Herkunft des ungarischen Namens Tátra. Finnisch-Ugrische Forschungen, 13, 171-178 [retrieved 24. 9. 2021 from https:/ / fennougrica.kansalliskirjasto.fi/handle/10024/91603].

Meyer, G. (1891). Etymologisches Wörterbuch der albanesischen Sprache. Strassburg: Trübner.

Meyer-Lübke, W. (1935). Romanisches etymologisches Wörterbuch. Heidelberg: Winter.

More, B. (Transl.). (1922). Ovid: Metamorphoses. Boston: Cornhill Publishing Co.

Morgenstierne, G. (1929). Indo-Iranian Frontier Languages, I: Parachi and Ormuri. Oslo: Aschehoug (Instituttet for sammenlignende kulturforskning).

Morgenstierne, G. (1974). Etymological Vocabulary of the Shughni Group. Wiesbaden: Reichert.

Mozley, J. H. (Transl.). (1957). Ovid: The art of love, and other poems. London - Cambridge (Mass.): Heinemann; Harvard University Press.

Muller, F. (1926). Altitalisches Wörterbuch. Göttingen: Vandenhoeck \& Ruprecht.

Novák, L. (2010). Jaghnóbsko-český slownik. Praha: Univerzita Karlova - Filozofická fakulta.

Olsen, B. A. (1988). The Indo-European Instrument Noun Suffix *-tlom and its Variants (Det Kongelige Danske Videnskabernes Selskab, Historisk-filosofiske Meddelelser, 55). Copenhagen: Munksgaard.

Orel, V. (1998). Albanian Etymological Dictionary. Leiden: Brill.

Pokorny, J. (1959). Indogermanisches etymologisches Wörterbuch. Bern - München: Francke.

Pražák, R. (1988). Legendy a kroniky Koruny uherské (Transl. J. Nechutová, \& D. Bartoňková). Praha: Vyšehrad.

Roberts, C. (Transl.). (1912). Livy: History of Rome. New York: Dutton and Co.

Rozwadowski, J. (1914). Tatry. Jezyk polski, 2(1), 11-14 [retrieved 24.09.2021 from http://mbc.malopolska.pl/dlibra/docmetadata?id=68890\&from=publication].

Rozwadowski, J. (1916). Przyczynek pochodzenia nazwy Tatr. Jezyk polski, 3(1), 17-18 [retrieved 24. 9. 2021 from http://mbc.malopolska.pl/dlibra/docmetadata?id=67914\&from=publication]. 
Schrijver, P. (1991). The Reflexes of the Proto-Indo-European Laryngeals in Latin. Amsterdam - Atlanta: Rodopi.

Schrijver, P. (1995). Studies in British Celtic Historical Phonology. Amsterdam - Atlanta: Rodopi.

Schumacher, S. (2004). Die keltischen Primärverben. Ein vergleichendes, etymologisches und morphologisches Lexikon (Innsbrucker Beiträge zur Sprachwissenschaft, 110). Innsbruck: Institut für Sprachen und Literaturen der Universität Innsbruck.

Shorey, P., \& Laing, G. J. (Eds.). (1919). Horace: Odes and Epodes. Chicago: Sanborn \& Co.

Smoczyński, W. (2018). Lithuanian Etymological Dictionary (ed. A. Holvoet, S. Young, \& W. Browne). Berlin - Bern - Bruxelles - New York - Oxford - Warszawa - Wien: Peter Lang.

Steingass, F. J. (1892, 1957). A Comprehensive Persian-English Dictionary, Including the Arabic words and phrases to be met with in Persian literature. London: Routledge \& Kegan Paul.

Stifter, D. (2020). Old Irish Etymology through the Ages. Language E History, 63(1), 24-46.

Stokes, W. (1891). The Second Battle of Moytura. Revue Celtique, 12, 57-130.

Stokes, W. (1893). The violent deaths of Goll, son of Carbad and Garb of Glenn Rige. Revue celtique, 14, 399-449.

Stokes, W. (1904). O’Davoran Glossary. In W. Stokes, \& K. Meyer (Eds.), Archiv für Celtische Lexikographie (Vol. II; pp. 197-504). Halle: Niemeyer.

Storr-Best, L. (Transl.). (1912). Varro: On farming. M. Terenti Varronis Rerum rusticarum libri tres, translated, with introduction, commentary, and excursus. London: Bell \& Sons [retrieved 24.09.2021 from https://archive.org/details/varroonfarmingmt00varr].

Summers, W. C., \& Postgate, J. P. (Eds.). (1905). Silius Italicus: Punica. In Corpus Poetarum Latinorum (Vol. 2). London: Sumptibus G. Bell et Filiorum [retrieved 24.09.2021 from https://www. thelatinlibrary.com/silius/silius8.shtml].

Szemerényi, O. J. L. (1996). Introduction to Indo-European Linguistics. Oxford: Clarendon Press.

Thurneysen, R. (1946). A Grammar of Old Irish. Dublin: Dublin Institute for Advanced Studies.

Tischler, J. (1993). Hethitisches etymologisches Glossar. Mit Beiträgen von Günter Neumann E̋ Erich Neu. Teil III, Lieferung 9; T, D/2 (Innsbrucker Beiträge zur Sprachwissenschaft, 20). Innsbruck: Institut für Sprachwissenschaft der Universität Innsbruck.

de Vaan, M. (2008). Etymological Dictionary of Latin and the Other Italic Languages. Leiden - Boston: Brill.

Vasmer, M. (1986-1988). Ėtimologičeskij slovaŕ russkogo jazyka (Transl. O. N. Trubačev; Vols. I-IV). Moskva: Progress.

Walde, A., \& Hofmann, J. B. (1938-1954). Lateinisches etymologisches Wörterbuch (Vols. I-II). Heidelberg: Winter.

Warmington, E. H. (Ed. \& Transl.). (1935). Remains of old Latin, I: Ennius and Caecilius. Cambridge: Harvard University Press.

Weiss, M. (2009). Outline of the Historical and Comparative Grammar of Latin. Ann Arbor - New York: Beech Stave Press.

Weissenborn, W., \& Müller, H. J. (Eds.). (1898). Titus Livius: Ab urbe condita. Leipzig: Teubner.

Williams, Th. C. (Transl.). (1910). Vergil: Aeneid. Boston: Houghton Mifflin Co.

Yonge, C. D. (Transl.). (1856). M. Tullius Cicero: For Archias. In Idem (Transl.), The Orations of Marcus Tullius Cicero. London: Henry G. Bohn.

Zair, N. (2012). The Reflexes of the Proto-Indo-European Laryngeals in Celtic. Leiden - Boston: Brill. 
Zimmer, S. (2000). Studies in Welsh Word-Formation. Dublin: School of Celtic Studies, Dublin Institute for Advanced Studies.

Żelechowski, E., \& Niedzielski, S. / Želexovskyj, E., \& Nedilskyj, S. (1886). Ruthenisch-deutsches Wörterbuch / Malorussko-nimeckyj slovar (Vol. II). Lemberg / Lviv: Szewczenko / Ševčenko.

\section{Acknowledgement}

I would like to express my thanks to John Bengtson and Stefan Zimmer for correction of English and again to Stefan Zimmer, Harald Bichlmeier and especially Michael Weiss for their valuable comments, additions and corrections.

prof. RNDr. Václav Blažek, CSc. / blazek@phil.muni.cz

Department of Linguistics and Baltic Languages

Masaryk University, Faculty of Arts

Arna Nováka 1, 60200 Brno, Czech Republic 